\title{
LEGAL TRANSFORMATION AND THE IMPACT OF INTERNATIONAL HUMAN RIGHTS MECHANISMS: THE CASES OF TURKEY AND RUSSIA
}

\author{
Ralf ALLEWELDT*
}

\begin{abstract}
:
This paper compares Turkey and Russia with respect to their implementation of international human rights law. Both countries have entered important commitments by accessing to international human rights treaties including the European Conventions on Human Rights and on the Prevention of Torture. They have thus subjected themselves to enforcement and inspection mechanisms that should lead to an enhanced respect for human rights. Such a development, however, has so far only taken place in Turkey. Following numerous judgments by the Human Rights Court and recommendations by the Committee for the Prevention of Torture, Turkey has implemented legislative and administrative reforms that have led to a substantial improvement in the human rights situation. In Russia, which has only recently acceded to the human rights enforcement mechanisms, such a development cannot be made out so far. However it is submitted that the dynamics of an enforcement mechanism including individual applications, binding Court judgments and effective enforcement by an intergovernmental body like the Committee of Ministers of the Council of Europe are well-designed to lead to positive developments in Russia as well.
\end{abstract}

Keywords: Human Rights, Prevention of Torture, Implementation, Enforcement, Turkey, Russia.

Özt:

Bu makalede Türkiye ile Rusya uluslararast insan hakları hukukunu uygulama yönünden kyyaslanmaktadir. Her iki ïlke, Avrupa Insan Haklart ve Isskenceyi Önleme Sözleșmeleri'ni kapsayan uluslararast insan haklart

"Prof. Dr., Yeditepe University, IstanbuI; Privatdozent, European University Viadrina, Frankfurt (Oder), Gemany. 


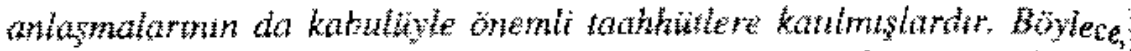
instm haklorma saysmin antmintasma youllk uygulama ve deneth

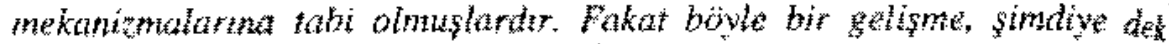

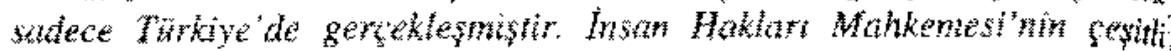

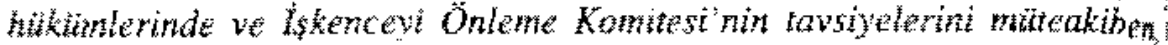

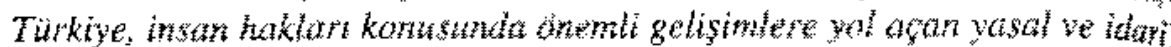

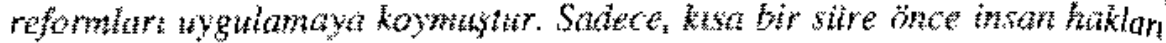

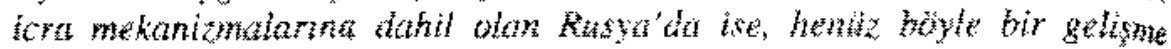

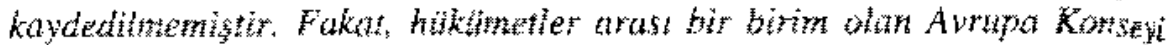

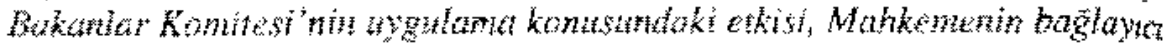

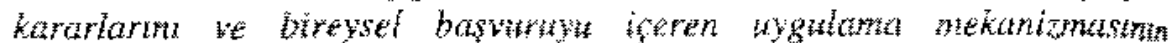

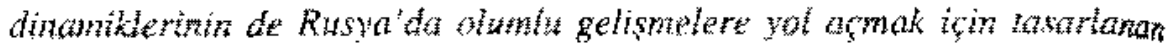
iyi gellimeler olduts

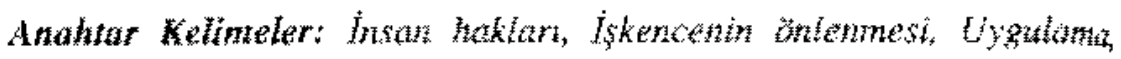
Tiirkige, Rusyta.

\section{Introduction}

Human rights law contains fules on how persons should be trealed by their own governmest. In this respect, the approach which was dominant in intemational law for a long time can best be described as indiference. Well into the $20^{\text {th }}$ century intemational law has zmonidered human rights protwetion to be an internal matter of states in which other states were not supposed to intervene. In other words, governments were. under international law, in a way obliged to be indifferent with regard to the suffering of persons in other countries. It was considered to be impossible that international faw could grant an individual tight to private persons. At the beginning of the 2 th cenury, bowever, this situation has changed considerably (Nowak, 2003: 16-30).

1: was in 1945 that the founding members of the United Nations look a rexplutionary step and included the promotion of human rights among the aitns lait down in their Chanter (UN Charter). The atrocties committed by the Gemman national-sotidist govenment motivted them to make hutnan rights a subject for regulation in international law. In 194 for $^{2}$ they adopted the Universat Dexlanation of fluman Rights: a list of rights as a common standard of achievement for ath satcs and pooples.

This declametion had a non-binting character atet did not seate individuat rights. Human fights acquired the foree of law only through the prowes of codifieation: their description in internationat treaties which had 
to be ratified by states (and today have been ratified by the majority of states). This codification took, at the universal level, about 40 years: wate now in possession of internatumal treaties on civin and political rights, wconomic, soctal and cultural rights, on the rights of women and children, against torture and discrimination.

We have found out very much about the content of human rights, but that, unfortunately has not prevented human rights from being violated at a very large scale throughout the world. Since the world conference on human rights took place in Vienua in 1993 human rights experts and activists agree that for human rights law the age of implementation and enforcenent is about to begin, or should begin now.

In Europe, developments have been somewhat faster than at the universal level. The binding furopean Convention on Human Rights was adopted as early as 1950 and entered into force in $1953^{2}$. From the begirning this Convention ontained an enforcement mechanism which was subject to a major reform in 1998. Since ther everyone within the jurisdiction of a Contracting State can apply to the European Court of Human Rights once he or she thinks that his or her human rights have been violated In 1987 the member states of the Councll of Eutope atopted a special Convention for the Prevention of Torture ${ }^{*}$.

It appears to be generally accepted that economic transformation should go hand in hand with respect for individual human wights as laid down in international human rights instruments. Promotion and protection of human rights are among the political criteria for accession to the European Union as atopted by the Europesn Council of Copenhagen." Respect for human rights is one of the fundaments and one of the important general aims of the European Union, ss expresset in Article 6 of the Treaty on European Union

'In the Freamble to the Viemta Declaration and Prograntme of Action (UN Doc. A/CONA $157 / 23$ of 12 July 1993 , govermments dexlare the cornotitnent to the "ufil realization of human rights", to "prevent the contimuation of hurnan tights violations" and to "secure full and universal enjoyment of these rights",

${ }^{2}$ Convention for the Protection of Human Rights and Fundamental Freedoms of 4 Novernber 1950 , ETS $\mathrm{Na}_{2}$.

${ }^{3}$ Article 35 of the Convention.

${ }^{7}$ European Convention for the Prevention of Torture and humumat or Deyrading Treatruent or Punishment of 26 Novernber 198\%, ETS No. 26.

S European Council in Copentagen, 21.22 June 1993, Conchusions by the Presidency 1-13: Bulletin of the European Conmunities 6/1993, p. 13. 
as well as in the Preamble and Article 2 of the dratu Constitutional Treaty. Human rigbts are the basis of the Common Foreign and Security Policy, of the European Neighborhond Policy and of the Strategie Partnership with Ruscitut.

\section{Human Rights Rhetorics and the Spiral Modd}

However, despite the many promikes and commitments to respect and protect human rights it is also wather obvious that we live in times of human rights metorics and even hypocrisy. In times where wars of atggession are conducted in the name of demberacy progress in the field of human rights protection cannot be measured by verbal and legal commitments alonc, but only by assessing the actual recepton, implementation and enforcement of human rights norms within the legal order and practice af states, in other words: by having a close look on the actual human rights situation and it possible improvement in a given country. When doing this, it is hetpful to conside the typical stages that states may pass on their way from a thuman rights violating to a human rights respecting country.

Risse, Ropp and Sikkink bave examined a number of countries in which the human rights situation had improved over the years and according to them, such improvements can be described (and party explaned) by a "spiral model" (Risse, Ropp, Sikkink, 1999: 233-250). It appears that the "sociatisation" of states in the feld of buman rights very often passes through five phases: in the tirst phase, regetsion, people live in a state where human rights are massively violated. People try to extablish domestic human rights orgatistations, to document human rights violations and bing them to the attention of the international community including internationat human rights NGOs. If they suceed, the human rights situation in this country is on the international agenda, and the government must somehow answer to theses chatges. Very ofter the reaction will be dental whoh is the seound phase of the model. Governments may dery that the intemational contmunity is entitled to discoss the situation of individuals in their territory, citing the principle of non-intervention in intemal affairs. They may atso keny the existence or scope of a patticular human right or the

S See. Article 11 para. I af the Treaty en European Union.

"See, as the moxt receot reference, Etropean Parliament Resolution on the European Nagighbouthoed Policy (2004/2166(INI)) of 19 Thuary 2006, no. I, t.

"Agreenum on Partnership and Conperation establishing a partnership between the European Commutities and their Merober States, of the one part, ayd the Russian Federation, of the other part, of 24 June 1994, Articles $1,6$. 
factual basis of the allegations. If the pressure is high enough, however, govemments move to the very important third phase of tactical concessions. This depends on the strength of the human rights networks and the degree to which the state is vulnerable to extemal pressure. States enact now policies which claim to safeguard human rights, and they enter into a domestic and international dialogue on human rights protection. This in tum leads to the fourth, prescriptive phase which means that states have been brought to accept international and national human rights norms as part of their legal order though not of everyday real life. The dynamics of this process will often lead either to a substantial liberalisation or to a constitutional or governmental change. The last phase of the spiral model is the phase of rule-consistent behaviour. In this stage international and national rules on human rights protection are generally respected though occasional abuses are possible.

Risse and his colleagues illustrate their model by conducting numerous case studies (Risse, Ropp, Sikkink, 1999). They do not state that these five steps are taken in each and every case but that many countries where a substantial improvement in the human rights situation has happened have passed these stages. While it is not the purpose of this paper to give a full analysis of developments in the human rights situation in Turkey and Russia in the light of the spiral model, it appears plausible that transition to the prescriptive phase where human rights are respected on paper but not in practice is normally achieved before human rights violations disappear in reality. That means that human rights rhetorics, even dishonest statements made by govemments, though not satisfactory from a human rights point of view, can, if seen in historic dimensions, be regarded as an important and necessary step on the way to rule-consistent behaviour.

The present paper deals with the situation in Turkey and Russia. These two countries have in common not only their geographical situation connecting Europe and Asia. Both countries had, in the past, governments whose priority was not to protect human rights and faced considerable problems in this field. Towards the end of the $20^{\text {th }}$ century, however, both countries acceded to the enforcement mechanism under the European Convention on Human Rights and to the inspection system under the European Convention on the Prevention of Torture ${ }^{9}$. The paper attempts to

9 Turkey had been a Contracting Party to the European Convention of Human Rights since 1954, but did not recognise the right to individual petition until 1987. Russia acceded to the Convention in 1998. 
analyse developments in the light of the standard laid down in these two convestions.

\section{IIt. Human rights law and the national legal order}

Article 15 of the Russian Constitution of 1993 provides for the priority of intemational treaties over national law. In addition, the Constitution itself contains a long list of human nights that cover the content of most human rights laid dowt in intemational treaties. The Turktsh Constitution of 1982, although created under miltary rule, also indudes a list of fundamental nights of the cituzen. Article 90 para. 5 provides that international treaties have foree wihin the internal legal order. Since a Constitutional Amendment was adopted in 2004 intemational human tughts acorts have priority over national law that contradicts them. Tutkey as well as Russia are Contracting Parties to the Furopean Convention of Human Rights and to the Convention for the Prevention of Torture. So we can see that, all in all, the norms of intemational human nights law are, from a kegislative and theoretical point of view, well protected in both Turkey and Russia. Both states have at least reached Phase 4 - the "prexeriptive" phase of the spizal model. In both countries, however, the implementation of these rutes has not been unproblematic.

\section{rV. Implementation and enforcement}

\section{Current human rights problems in Russia}

In Russia, human rights violations as reported by organtsations and institutions like Amnesy intemational (Al, 2005), Humar Rights Watch (HRW, 2006) and the U.S. State Department (2004) include numerous illegal executions of civil persons in Chechnya, frequent overcrowding of places of tetention to an extent that the conditions must be considered to be degrading, the exercise of pressure by the police on journalists who report on corruption, and the arbitrary non-registration or closure of private (human rights) associntions. It is not surprising that at the time of Russias accession to the Council of Europe in 1996 there was no agreement as to whether Russia had reached a level of human rights protection compatible with the aims and principles of that organisation:

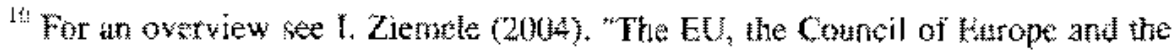
OSCE: Possibitites and Litrits of a Common Human Rights Polsy in Enrype". R.

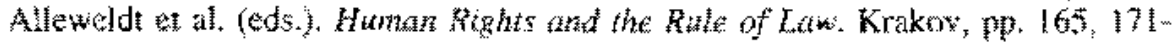
173. 
The judgments given by the European Court of Human Rights in 2005 reflect these problems. In the case of Khashiyev the Court found a violation of the right to life with regard to killings of civil persons in Chechnya ${ }^{\prime \prime}$. Such a violation was also found in the case of Trubnikov where a prisoner had apparently committed suicide; the Court did not establish that an unlawful killing had taken place but held that the lack of an effective investigation did not conform to the Convention ${ }^{12}$. In Romanov the conditions of detention in a psychiatric institution, long pre-trial detention and trial in absentia was found to be violating human rights ${ }^{13}$. The criminal conviction of a joumalist named Grinberg for criticism of a Region Governor was not compatible with his right to freedom of expression under Article 10 of the Convention ${ }^{14}$.

It must be added that, unfortunately, the lodging of an application with the Court may have serious and tragic consequences for an applicant. In Chechnya, Russian citizen Anzor Pokayev was taken into custody after his house had been searched and was found being shot some hours afterwards. His father had filed an application to the European Court of Human Rights in 2003 concerning the disappearance of another son. (AI, 2005)

Similarly, the European Committee for the Prevention of Torture (CPT) has encountered some problems on its visits to Russia. Its task is to visit places of detention, to examine the treatment and the conditions of detention of persons deprived of their liberty. It has certain powers including the power to interview detained persons in private. Subsequently it gives recommendations to the Government proposing, for example, to strenghten fornal safeguards like access of any detainee to a lawyer or a doctor. Its reports are confidential but it can issue a public statement if the Govemment refuses to cooperate or to improve the treatment of detainees in the light of the Committee's recommendations ${ }^{15}$.

With respect to Russia, the CPT has so far issued two public statements on the situation in Chechnya and one report concerning a visit to Russia in 2001. The co-operation encountered by the CPT was described as being only partly satisfactory. Inter alia, the CPT was incorrectly inforned so that

\footnotetext{
"Khashiyev and Akayeva v. Russiu, Judgment of 25 February 2005, para. 147.

${ }_{12}$ Trubnikov v. Russia, Judgment of 5 July 2005 , paras. 78, 95.

${ }_{14}^{13}$ Romanov v. Russia, Judgment of 20 October 2005, paras. 83, 101, 113.

${ }_{15}^{14}$ Grinberg $v$. Russia, Judgment of 21 July 2005, paras. 26-35.

${ }^{15}$ European Convention on the Prevention of Torture (n. 6), Articles 7-11.
} 
it travel places of detention whose existence was not communitated to the CPrity.

In the course of crimmal investigations, the main aim of the Russian Militia appears to be coxtract a confexion out of suspects with all avalable means including torture and ill-treatment ${ }^{7}$. At the time of the CPT's visit (December 2001) ut was clear that a new Code of Criminal Procedire wonde enter into fore in 3002 which stipulated that confestons mads whoth the presence of a lawyer and not conturmed by the suspect in court, awe not admissibus avidence. The ClT welcomed these provistons, but

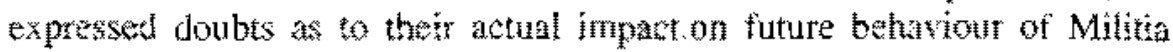
afficals. The C1PT delegation spoke to many memats of the Militia of all ranks about their thoughts on these reforms, ant the "consistent and unwavering response was that the new provisons were unlikely to generate

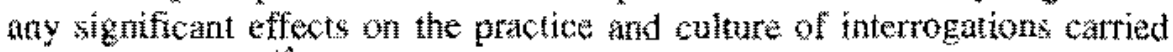
ont by the Militia! ${ }^{\text {: }}$.

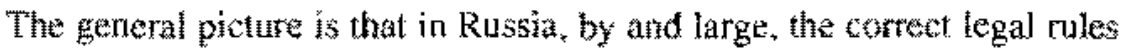
may be in harce, but in mayy sases ney are distegarded by the Russian athorities.

\section{The situation in Turkey}

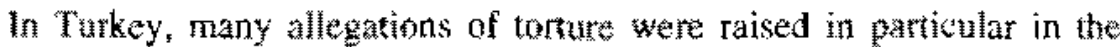
attermath of the mititary coup in 1980 . A state applicsion claiming, inter alta, violations of the prohibition of thrture was lowed with the European

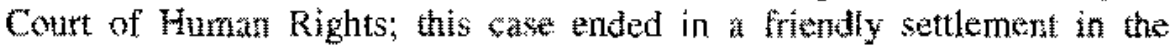
context of which Turkey entertet a number of ommitments in orter to inprove the protection of human rights ${ }^{19}$. Some patterns in the human rights situation in Turkey hate been similar to that of Russia. The CPT began its regnlar visits in 1990 , and in its first pablic statement af 1992 the Committee complaned about the lack of comoperation entam the par of

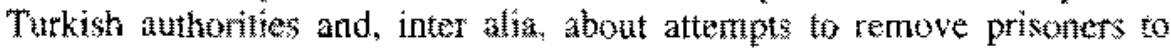

5eport to the Russian Government on the visit to the Russian Feteration carrict

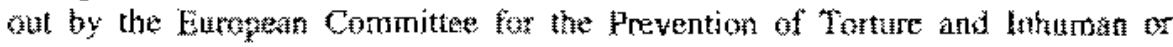

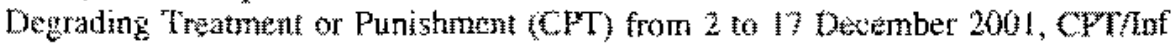
$(2003) 30$, para. 8 .

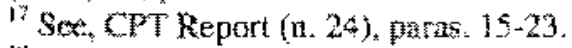

I' Sez, CTI Report ín. 24), Hafa. 22 .

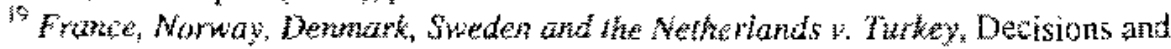
Repants of the Eutonean Commisstun of Humato Rights $44,31$. 
prevent them from speaking to the $\mathrm{CPT}^{20}$. The Committee, in 1992, considered torture and other forms of ill-treatment to be important characteristics of police custody in Turkey ${ }^{21}$. In 1990 Turkey recognised the jurisdiction of the European Court of Human Rights, and after this recognition an ever accelerating avalanche of cases started rolling to the Strasbourg Court. In many of these cases the Court has found that Turkey has violated human rights including the right to life ${ }^{22}$, the prohibition of torture $^{23}$ or freedom of expression ${ }^{24}$, that persons had been made "disappear" ${ }^{25}$ or subjected to an unfair trial ${ }^{26}$.

Turkish authorities did apparently not appreciate to be brought by their own citizens before international courts: a number of applicants were subjected to pressure by police or prosecuting authorities ${ }^{27}$; one of the first applicants, Mr Aksoy, was killed under unclear circumstances ${ }^{28}$. After some years had passed, however, things started to change. On CPT recommendations the period of maximum incommunicado detention was shortened considerably, the internal rules on interrogations were amended, and police officers were frequently reminded that torture and ill-treatment are not acceptable methods of work for the police ${ }^{29}$. On the governmental level numerous initiatives against torture were started, supported inter alia by Council of Europe advice. It took some years until these efforts reached

${ }^{20}$ European Committee for the Prevention of Tonure, Public Statement on Turkey of 15 December 1992, CPT/Inf 93 (1), para 7.

${ }^{21}$ Ibid., paras. 4, 21 .

${ }^{22}$ See, e.g., Mahmut Kaya, Judgmeut of 28 March 2000; Ağdaş, Judgment of 27 July 2004; Simşek, Judgment of 26 July 2005.

${ }^{23}$ Salman, Judgment of 27 Juue 2000; Akkoç, Judgment of 10 October 2000.

${ }^{24}$ Karademirci, Judgment of 25 Janunary 2005; Birol, Judgment of 1 March 2005; Kürkçü, Judgment of 27 July 2004.

${ }^{25}$ Orhan, Judgment of 18 June 2002; Timurtas, Judgment of 13 June 2000; Taş, Judgment of 14 November 2000.

${ }^{26} \mathrm{Kolu}$, Judgment of 2 August 2005; Sener, Judgment of 18 July 2000.

${ }^{27}$ Sarl , Judgment of 22 May 2001; Akdeniz, 31 May 2001; Orhan, Judgment of 18 June 2002.

${ }^{28}$ Aksoy v. Turkey, Judgment of 18 December 1996, paras. 101-106.

${ }^{29}$ Cf., e.g., Report to the Turkish Government on the visit to Turkey carried out by the European Committee for the Prevention of Torture and Inhuman or Degrading Treatment or Punishment (CPT) from 5 to 17 October 1997, CPT/Inf (1999) 2, para. 14-54; Report on the visits from 21 to 27 March and 1 to 6 September 2002 , CPT/Inf (2003) 28, para. 28; Report on the visit from 7 to 15 September 2003, CPT/Inf (2004) 16, para. 6. 
the level of everyday police acitivitues, bot in 2003 detuined persons at Turkish police stations stated that their treatment was much better than it used to be, and they were surprised that gendarnes started to intorm them as to their nights ${ }^{30}$. The problem of torure and ill-treatrment by the police in Tukey is certainly not solved completely, but it appeas that the treatment of persons in police custody hus improved considerably.

Futher structural human rights problems have been tachled by legiglative measures. In 2002 a right to a retrial was introduced for persons that had suffered from an unfair trial, in 2004 the death penalty was abolswed with respect to all erimes wher in war or peacetine. Equally in 2004 a more liberal press law and law of associations were adopted as well as a law containing a right to compensition for tetople who lost thet home in the course of the fightings in South-Eastern Turkey.

Still many persons bring cases against Turkey to the European Court of Human Rights, In 2005 therr number was approximately 2000; 240 were declared admissible. In 2003 , however, the number of applications had been about 4000 , in 2003 about $3000^{32}$. It appears that thete is presently a downwards trend in the number of applications lodged with the Cours and a clearly positive trend with respect to the overall human rights situation.

\section{Effectiveness of the Convention system with regard to Russia}

In Russia the effectiva application of the European Convention on Hutnan Rights is canainly still in its stating phase. Fe judgments have been adopted with respect to Rusxia in Strasbourg: five judgments in the year 2003,15 in 2004 and finally 82 in $200 \%$. In 2005.8000 new applicutions were filed against Russia and 110 declared admissible.

It appears thar once a state has subjected itself to the Convention system applicants, all in all, cannot be stopped. The Convention system has proven to be a slow but to a large extent sustainable mechanism for the protection of human rights. Judgments of the European Court finding a human rights violation have a negative effect on the image of the state concemed, and they also show to governments that human rights violations are cxpensive in

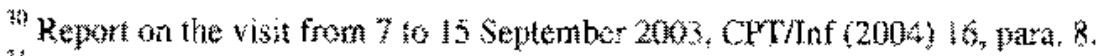

3 See, e.g. H. Cuntume (2005). "Retorms in the Turkigh Legal System in the Context af the Copenhagen Political Criterin", H. Kabralogla at. al. The

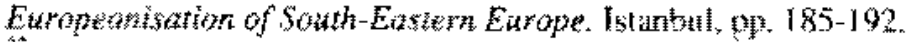

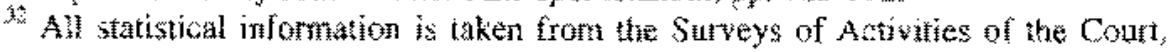

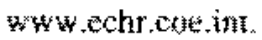


that a monetary compensation has normally to be paid as "just satisfacton ${ }^{\text {it }}$ to each applicant ${ }^{33}$. "whe Committee of Ministers of the Conncil of Europe supervises the exation of judgtnents ${ }^{34}$ and, in the case of structurat deficiencies, expects from comacting states to prevent future human rizhts violations by introducing changes in domestic legislation and practive ${ }^{35}$. They will take up the same matter, if necessary, agais and again: ine debates in the Commite of Mintsters constitute an ongonng dialogue on human rights issues, a dialogus which is sometimes missed in other institutions like for instance, the United Natons Human Rights Commission. Not all cases brought before the European Court are of a highly politicat nature; the applicant in Solodyuk complained of a consiferable delay in pension payments ${ }^{36}$, and 37 judgments adopted in 2005 concerned the non-enforcement of civil count decisions (ECHR, 2005. 22). In Ryabykh a domestic civil count hat given final judgment for the applicant, but this jutgment had been quashed subsequenty in a stopervisory review procedure intiated by the president of the civil court. The Emropean Count considered this procedure, which was not subject wo any time limit, to be incompatible with the principle of legal certainty and thus unfair ${ }^{30}$. In such non-political cases which can hardly be tabjused for political aims it is not very probable that the lussian Covermment will pernanently refuse to enter into a ditalogue and to improve the situation in the light of the Court's judgments. In fact, the provisions on the supervisoryreview procedure have been amended in 2003 althotgh perbaps not to a sufficiently large extent ${ }^{\text {*a }}$. The Code of Criminal Procedure has in act been antendec in 2002, and it appears that, in spite of the expectations on the part

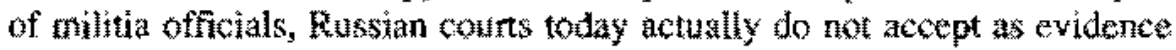
confessions mate by suspects in police oustody untess a lasyer has been present (U,S. State Department, 2004). In the Committee of Ministers, human nights are discussad on a tiplomatic level; the enforcement of humal rights in this body is instinutionalized, perhaps even bureaucratized, ank it

${ }^{32}$ Con. Artiole 41 of the European Convention on Fuman Rights.

It is anpowerest and obliged to do so under Article 46 of the Convention.

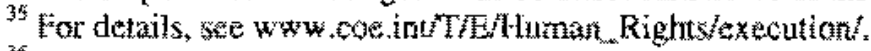

36 Solodyatik v. Russia, Jutgment of I 2 July pons.

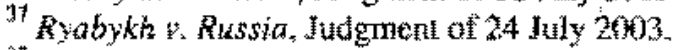

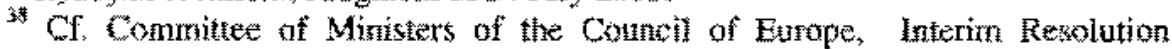

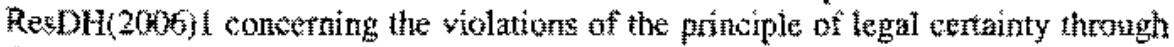

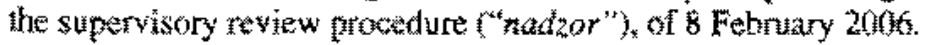


may be sactly this proces which contributes to the long-term effectiveness of the Convention system.

\section{Conclusion}

Why is human wights protection af such a cructal importance? Human rights awt human dignity are the basis of society, of the contrat watidi. Rule of law means that govenments are constituted by law and act through law and not (merely) through power. Once a govonment ceases to take seticus the most fundamental norm of latu - to respect the tignity of all people subjected to its ale - the logical consequence will be that the governed will in the course of time lose all respect far the law as well. How can a govemment which distespects fundamental rules of law be justified in expecting from its citizens to respect the rules made by this government as "law"? This may be not just a philosophical, but a legal question. Human rights violations are capable of undemining the whole ides of law as binding rules between citizens and governments. Unfortunately, such violations persist in many countrics. It must be highy appreciated it govennenty decide to subject thernselves to international control mechanisms like the ones established under the European Convention on Human Rights and under the Convention tor the Prevention of Torture.

In sum we see that Turkey has gone far beyond the stage of merely entering commitments: Turkey is moving towatis respecting the rules of human rights law. We cannot, as matters stand, draw the same conclusion with regard to Russia, Experience shows, however, that at present there is no need to give up hope. The "spiral model" so tar has not beent falsiffed with respect to Russia,

Ou the other hand, nothing in this paper should be understood to the effect that the imptementation and enforcement of international human rights law is something like an automatic proesss. Not one single case in Strashour is won "automatically" -. the fight for human rights is painstaking work, We can never be stre that human rights will be securto permanently; the respect for human nights certainly requires the pemaneat vigilance of everyone. 


\section{Raferences:}

Amnexty Intenational, Anmual Report 2005, Russia. Retrieved From: http:/web.amnesty org/teport2005inus-surnmary-eng.

European Court of Human Rights. Suney of Activities 2005. Retrieved from: sww.echrcee.int.

Günigilir, H (2005), "Reforms in the Turkish Legal System in the Context of the Copenhagen Political Criteria". H. Kabaalioglu et. al. The Europeanisation of South-Eastern Europe. Istanbul

Human Rights Watch, Human Rights Ovewiew Russid. Retrieved from: btp:/hrw org/english/docs $2006 / 01 / 18$ /russial2218.htm.

Nowak, M. (2003). Introduction to the International Human Rights Regime. Leiden/Boston.

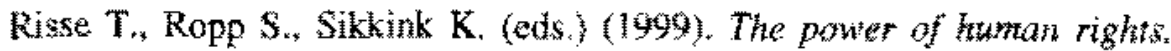
New York.

UN Charter, Freamble and Article I no. 3.

U. S. State Department, Couniry Repons on Human Rights Practices 2004. Russin. Sections 1 and 2.

Zienele, I. $(2004)$. "The EU, the Council of Europe and the OSCE: Possibilities and Limits of a Common Human Rights Policy in Europe". R. Alleweldt et al. (eds.). Haman Rights and the Rule of Law. Krakow. 